\title{
Varicella Zoster Virus Infection in Pregnancy
}

\author{
Irena Narkeviciute ${ }^{1}$ and Jolanta Bernatoniene ${ }^{2}$ \\ ${ }^{1}$ Vilnius University Clinic of Children's Diseases, \\ ${ }^{2}$ Bristol Royal Hospital for Children, \\ ${ }^{1}$ Lithuania \\ ${ }^{2} U K$
}

\section{Introduction}

Varicella-zoster virus (VZV) is one of the eight herpesviruses that infect humans. The virus causes two diseases: the primary infection, varicella (chickenpox), and secondary or clinical manifestation of latent infection, herpes zoster (shingles). Though VZV infection rarely occurs during pregnancy, the disease is likely to be associated with significant complications for both mother and fetus: pregnant women are several times more likely to develop fatal varicella than non-pregnant patients, the fetus is at high risk of congenital varicella syndrome (CVS), and the neonate is at high risk of a severe or fatal form of varicella.

\subsection{Varicella}

Ninety percent of varicella cases occur in children between the age of 1 and 14 years. Varicella is a highly contagious disease and affects nearly all susceptible children with an attack rate approaching $90 \%$ following a household exposure to the illness. Transmission occurs mainly via direct contact and through respiratory droplets that contain the virus, making the disease highly contagious even before the first onset of rash. Varicella is generally regarded as a mild, self-limited viral illness with occasional complications in healthy children, and it is usually characterized by fever, malaise, and vesicular rash on the trunk, face, scalp, extremities, and oropharynx. The incubation period is usually 14-16 days, but can range from 10 to 21 days. The incubation period may be prolonged to 28 days if varicella zoster immunoglobulin (VZIG) has been administered. Transplacental transmission from mother to fetus occurs during maternal viraemia, and the incubation period for neonatal infection is 11 days (range 9-15 days) from the onset of maternal disease. The period of infectivity begins 1-2 days before the appearance of rash until the lesions crust over, usually 4 to 5 days after the onset of the rash (Centers for Disease Control and Prevention [CDC], 1996; Riley, 1998). Initially, the lesions appear as macules which tend to progress to vesicules which may erupt every 1-2 days. Once ruptured, these vesicules crust over. The lesions may be at various stages in the same area of skin and the rash is characteristically pruritic. The illness normally evolves over about 5 days.

Seroepidemiological studies performed between 1973 and 2000 in different industrial countries revealed that up to $26 \%$ of women of reproductive age do not possess VZVspecific IgG class antibodies (Sauerbrei \& Wutzler, 2005). Currently, most pregnant women living in the US and Europe are not susceptible to the development of varicella, because 
more than $90 \%$ of women of childbearing age are protected by virus-specific IgG class antibodies. The average incidence of varicella in pregnant women has been calculated as 2-3 per 1,000 pregnancies (Enders \& Miller, 2000). The epidemiology of varicella differs between countries with temperate climates and those with tropical climates. VZV is acquired at less frequency and at older ages in tropical and subtropical geographical zones. The rate of susceptibility to VZV is $16 \%$ (CDC, 1996). The latest seroepidemiological study carried out in 7980 pregnant women from various regions of the word demonstrated a prevalence of VZV antibodies of $93.1 \%$ in women born in Western European countries and $80.3 \%$ in women born in Central and Eastern Europe, Asia and Africa (Knowles et al., 2004).

Although the clinical course of varicella in children is usually mild, it may be severe or fatal in pregnant women. Varicella is estimated to be 25 times more likely to be severe in adults than in children. There is thought to be an even greater risk associated with pregnancy, particularly during the third trimester. Presumably, this is caused by maternal immunosuppression, which is most intense during this period (Gershon, 2001).

\subsection{Herpes zoster}

Herpes zoster (HZ) is caused by reactivation of latent VZV infection in sensory nerve root ganglia, which resulted during the attack of primary varicella infection. It usually occurs in about $15 \%$ of people over their lifetime, most commonly in elderly and immunocompromised populations. People with herpes zoster are capable of transmitting VZV to varicella susceptible individuals, although the patients with zoster infection are thought to be less infectious than the patients suffering with the primary varicella. Herpes zoster or shingles is characterized by a painful, unilateral vesicular rash that is usually restricted to unilateral dermatomal distribution and can occur on the trunk or face, although the rash may involve an extremity. The lesions, full of infectious virus, tend to coalesce. The individual is considered contagious to varicella susceptible until the skin lesions have dried. Most lesions may be present for days to weeks in immunocompromised patients. Pain is often a major complaint rather than itching. Zoster seems to increase in severity with increasing age; young people rarely have a severe form of the illness. Zoster is essentially not a fatal illness in otherwise healthy individuals. There is little information on the risk of developing zoster during pregnancy. Fortunately, herpes zoster during pregnancy and during the perinatal period is not associated with any known birth defect and problems for newborns, unless the women are immunocompromised (Enders et al., 1994; Miller et al., 1989; Sauerbrei \& Wutzler, 2000).

\section{Varicella in pregnancy}

If the pregnant women give a history of contact with varicella or shingles, a careful history including previous vaccinations must be taken to confirm the significance of the exposure and the susceptibility of the patient. The women should have a blood test to assess the presence or absence of the immunity to varicella. The algorithm for the assessment and management of varicella exposure during pregnancy is demonstrated in figure 1.

Varicella is much less common in adults than in children; however, it is associated with greater morbidity and mortality. Varicella results in the death of 25 people/year in England and Wales and $75 \%$ of these deaths occur in adults (Rawson et al., 2001). The data suggest that $5-14 \%$ of adults with varicella develop pulmonary involvement, which 
may vary in severity from a subclinical form, only detected on X-ray or lung function tests, to a severe and potentially fatal illness (Nathwani et al., 1998). The disease usually develops within 3-5 days of the rash and is associated with cough, dyspnea, fever, and tachypnea. Additionally, cyanosis, pleuritic pain in the chest, and hemoptysis can occur and secondary bacterial infections are frequent. The chest $\mathrm{X}$-ray findings include a diffuse or nodular infiltrative pattern often seen in peribronchial distribution involving both lungs. The X-ray findings may be more severe than the clinical appearance (Daley et al., 2008; Haake et al., 1990).

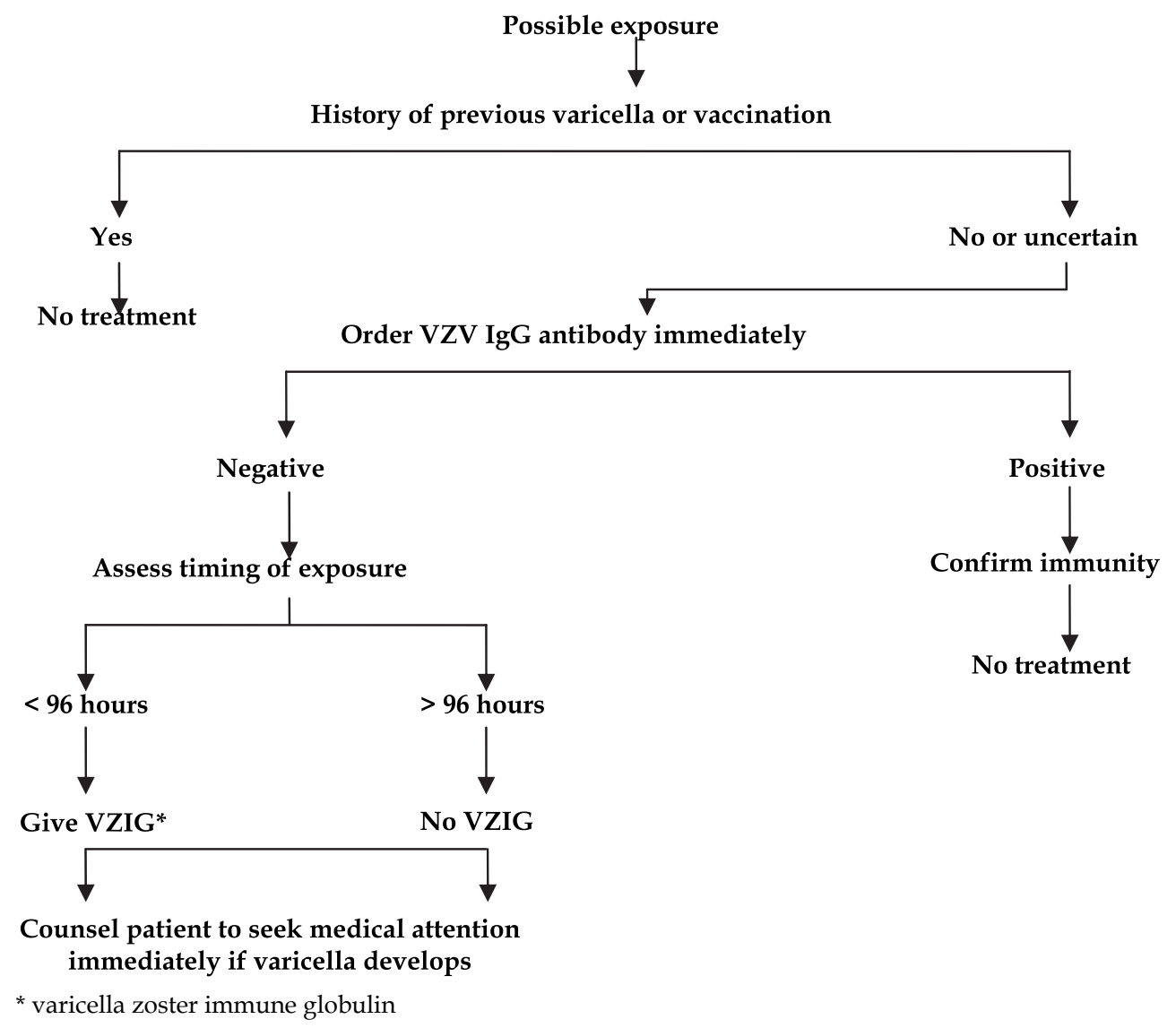

Fig. 1. Management of exposure to varicella during pregnancy (Gardella \& Brown, 2007, as cited in Heuchan \& Isaacs, 2001) 
Pregnant women appear no more likely than other adults to develop pneumonia (Royal College of Obstetricians and Gynaecologists [RCOG], 2001) which can occur in up to $10 \%$ of pregnant women suffering with varicella (Harger et al., 2002); however, varicella pneumonia may be more severe in pregnant compared to non-pregnant women. The severity of this complication seems to increase in later gestation (Tan \& Koren, 2005). Smoking and the occurrence of at least 100 skin lesions are well known risk factors for the development of VZV pneumonia (Harger et al., 2002). The mortality rate in untreated pregnant women is as high as $40 \%$ (Haake et al., 1990), therefore varicella pneumonia in pregnancy is considered a medical emergency. However, more recent studies suggest that the mortality has decreased to $10-11 \%$ for both non-pregnant and pregnant patients, most likely due to the effective antiviral therapy and better respiratory management (Chandra et al., 1998).

Encephalitis causing acute cerebellar ataxia can occur up to 21 days after the onset of the varicella rash (Sissons, 2003). Fortunately, more severe forms of encephalitis are uncommon (0.1-0.2\% of cases of varicella), but they have a mortality of around 5-20\% (Sissons, 2003).

Possible haemorrhagic complications of chickenpox include acute thrombocytopenia, or purpura fulminans associated with arterial thrombosis and haemorrhagic gangrene (Sissons, 2003). Although encephalitis and haemorrhagic complications are rare, their development may severely complicate pregnancy. Multiorgan involvement including hepatitis, myocarditis, and pericarditis is associated with a high mortality. Fetal loss may result from maternal sepsis, fever and hypoxia (Daley et al., 2008).

There is no evidence that uncomplicated chickenpox in the mother significantly increases the likelihood of spontaneous abortion during the first 20 weeks of pregnancy $(3.0 \%$ in one study) or intrauterine death after the 20th week (0.7\%) (Enders et al., 1994; Hinshaw \& Fayyad, 2000; Office for National UK Statistics, 2005).

\section{Management of the pregnant woman who develops varicella or herpes zoster}

Most pregnant women who develop varicella illness do not require hospitalization; they can be reassured and sent home for daily or more frequent reviews if clinically indicated (Morgan-Capner et al., 2002). Indications for referral to hospital include the development of respiratory or/and neurological symptoms, a wide-spreading haemorrhagic rash or bleeding, a dense rash with or without mucosal lesions, the appearance of new lesions after 6 days, and a history of significant immunosuppression. Also, the women close to term should be considered for hospitalization because of the risk of developing haemorrhagic complications or varicella of the newborn (RCOG, 2001). Furthermore, if the woman smokes cigarettes, has chronic lung disease, is taking corticosteroids, or is in the latter half of pregnancy, a hospital assessment should be considered, even in the absence of complications (Heuchan \& Isaacs, 2001; RCOG, 2001).

If the pregnant woman develops the first signs of chickenpox illness, an appropriate treatment should be decided in consultation with a multidisciplinary team: obstetrician or fetal medicine specialist, virologist, and neonatologist. Depending on the severity of the maternal condition, a respiratory physician, intensive care specialist, and infectious disease specialist may also be involved. Timing and mode of delivery must be individualized (Morgan-Capner et al., 2002; RCOG, 2001).

As the only safe therapeutic agent, acyclovir is indicated for pregnant women with varicella. The studies suggest that acyclovir administered in a dosage of $800 \mathrm{mg}$ five times a day for 7 
days reduces the duration of fever and symptomatology of varicella in immunocompetent patients if commenced within 24 hours of developing the rash when compared with placebo (Wallace et al. 1992). This randomized controlled trial did not have sufficient power to comment on the impact of early oral acyclovir on the serious complications of varicella. Data suggest that there is no increase in the risk of fetal malformation with acyclovir in pregnancy, although the theoretical risk of teratogenesis persists in the first trimester (Ratanajamit et al., 2003; Stone et al., 2004). Intravenous acyclovir (10mg/kg three times daily for at least 5 days (7-10)) is indicated for pregnant women with severe illness, complications and/or risk factors (Kempf et al., 2007; Morgan-Capner et al., 2002). VZIG has no therapeutic benefit once varicella has developed (Nathwani et al., 1998).

The woman may also need symptomatic relief with paracetamol and/or ibuprofen, although ibuprofen should be avoided after 30 weeks of gestation because it may cause premature closure of the ductus arteriosus (Prodigy, 2005). Systemic antihistamines should also be avoided during the first trimester and breast-feeding (Prodigy, 2005; Drug and Therapeutics Bulletin [DTB], 2002).

Delivery during the viraemic period may be extremely hazardous. There are significant maternal risks associated with bleeding, thrombocytopenia, disseminated intravascular coagulopathy, and hepatitis. Also, there is a high risk of varicella of the newborn with significant morbidity and mortality (Meyers, 1974; Miller et al., 1989). Therefore, where relevant and practical, the delivery should be delayed until 5 days after the onset of maternal illness to allow for passive transfer of antibodies that could protect the baby from the infection (RCOG, 2001). Supportive treatment and intravenous acyclovir is therefore desirable, allowing resolution of the rash, immune recovery, and transfer of protective antibodies from the mother to the fetus. Delivery may be required in women to facilitate assisted ventilation in cases where varicella pneumonia is complicated by respiratory failure (RCOG, 2001).

There is no evidence available to us to inform decisions about the optimum method of anaesthesia for women requiring delivery by caesarean section. General anaesthesia may exacerbate varicella pneumonia. There is a theoretical risk of transmitting the VZV from skin lesions to the central nervous system via spinal anaesthesia. This results in advice that epidural anaesthesia may be safer than spinal anaesthesia, because the dura is not penetrated. A site free of cutaneous lesions should be chosen for needle placement (Brown et al., 2003).

Women hospitalized with varicella should be nursed in isolation from babies or potentially susceptible pregnant women or non-immune staff (RCOG, 2001).

Treatment of herpes zoster in imunocompetent pregnant women should be symptomatic; topical or systemic antiviral therapy is not recommended (Kempf et al., 2007).

\section{Consequences of varicella in pregnancy}

Varicella acquired during pregnancy may have serious consequences for fetus and neonate. Maternal varicella associated with viraemia can transmit the virus to the fetus by either transplacental route or by ascending infection from the lesions in the birth canal. The possible outcomes of VZV infection during pregnancy depends on the time of the disease and includes spontaneous abortion, fetal malformation, premature delivery, fetal growth restriction, or postnatal infection. In infancy, herpes zoster may be the first clinical manifestation of VZV infection after the primary infection in utero (Table 1). 


\begin{tabular}{|c|c|c|}
\hline Maternal disease & Timing during pregnancy & $\begin{array}{l}\text { Consequences for mother, fetus, term } \\
\text { neonate }\end{array}$ \\
\hline Varicella & $\begin{array}{l}\text { At any stage } \\
\text { 5-24th weeks } \\
\text { At any stage, especially in } \\
\text { the third trimester } \\
\text { Near term: } \geq 5 \text { days before } \\
\text { delivery } \\
\text { Near term: } \leq 4-5 \text { days } \\
\text { before to } 2 \text { days after } \\
\text { delivery }\end{array}$ & $\begin{array}{l}\text { Intrauterine death, neonatal or } \\
\text { infantile zoster } \\
\text { Congenital varicella sindrome (risk: } \\
2 \% \text {, mortality: } 30 \% \text { ) } \\
\text { Maternal pneumonia (risk: } 10-20 \% \text {, } \\
\text { mortality: } 10-45 \% \text { ) } \\
\text { Neonatal varicella at ages } 10(-12) \text { days } \\
\text { (risk: } 20-50 \% \text {, mortality: } 0 \% \text { ) } \\
\text { Neonatal varicella } 0-4 \text { days after birth } \\
\text { (risk: } 20-50 \%, \text { mortality: } 0-3 \%) \text {; } \\
\text { neonatal varicella 5-10 (-12) days after } \\
\text { birth (risk: } 20-50 \%, \text { mortality: } 20-25 \% \text { ) }\end{array}$ \\
\hline Normal zoster & At any stage & $\begin{array}{l}\text { No risk for severe maternal, fetal or } \\
\text { neonatal infections }\end{array}$ \\
\hline
\end{tabular}

Table 1. Potential consequences of varicella-zoster virus infections during pregnancy (Sauerbrei, 2010)

\subsection{Congenital varicella syndrome}

Since the first report in 1947 (Laforet \& Lynch, 1947) more than 130 cases of congenital varicella syndrome have been described in the English and German literature (Sauerbrei \& Wutzler, 2005). CVS can occur in about 12\% of infected fetuses (Prober et al., 1990). Prospective studies in Europe and North America demonstrated that the incidence of congenital anomalies after maternal varicella in the first 20 weeks of pregnancy is about 12\% (Enders et al., 1994; Pastuszak et al., 1994). Before the 5th and after the 24th gestational weeks, the probability of CVS is extremely low (Sauerbrei, 2010). Overall the incidence of CVS in nine reported cohort studies was $0.55 \%$ in the first trimester, $1.4 \%$ in the second trimester, and $0 \%$ in the third trimester (Tan \& Koren, 2006).

Although a few cases of fetal abnormalities have been reported after maternal herpes zoster, clinical evidence suggests that herpes zoster infection during pregnancy does not cause the congenital varicella syndrome or neonatal varicella. This is because the fetus passively acquires, and is protected by, the mother's varicella antibodies produced in response to the initial varicella infection (RCOG, 2001).

Congenital varicella syndrome is usually characterized by unusual cutaneous defects with cicatricial skin scars in dermatomal distribution, neurological defects secondary to probable intrauterine VZV encephalitis (cortical atrophy, spinal cord atrophy, limb paresis, seizures, microcephaly, Horner's syndrome, encephalitis, mental retardation), eye disease (microphthalmia, enophthalmia, chorioretinitis, cataract, nystagmus, anisocoria, optic atrophy), limb hypoplasia or diminished limb growth, and other skeletal anomalies. Less frequent abnormalities include muscle hypoplasia and affections of the internal organs as well as gastrointestinal, genitourinary, and cardiovascular manifestations (Sauerbrei, 2010).

It is not known whether VZIG reduces the risk of CVS. A prospective study was carried out in 108 women who developed varicella infection despite VZIG prophylaxis. Eighty percent of these women received VZIG in the first and second trimester and there were no cases of 
CVS or infants with IgM antibodies at birth reported (Enders \& Miller, 2000). However, no conclusion can be drawn from this, given the rarity of CVS. Criteria for diagnosis of CVS listed in Table 2.

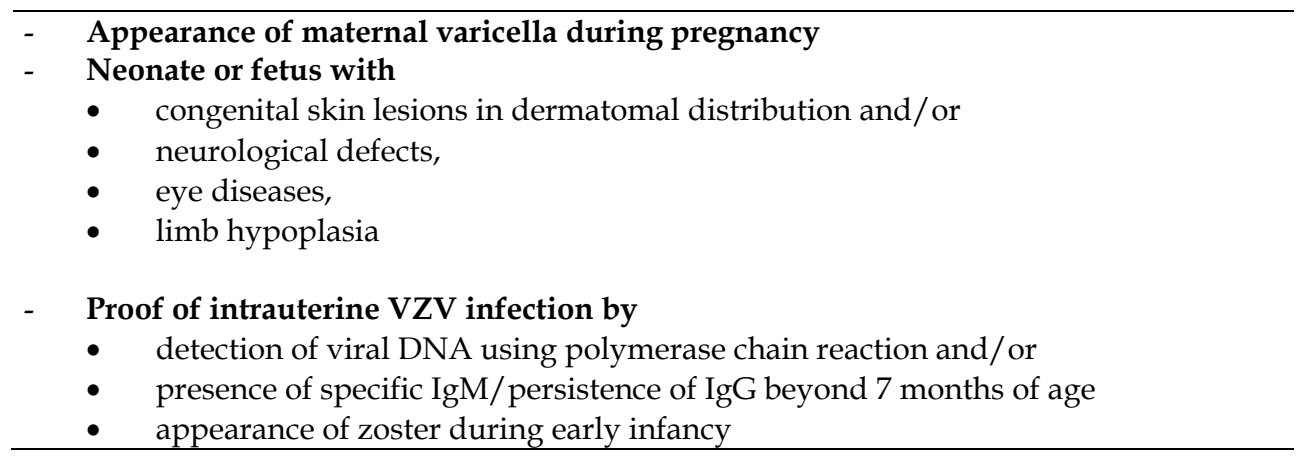

Table 2. Criteria used for diagnosis of congenital varicella syndrome (Sauerbrei, 2010)

Prenatal diagnosis of CVS is possible using detailed fetal ultrasonography and/or fetal magnetic resonance imaging and can be useful to look for limb anomalies or other morphological abnormalities caused by intrauterine varicella. VZV DNA can be detected by PCR in fetal blood, amniotic fluid, or placental villi. VZV IgM in fetal blood can be detected. No cases of CVS occurred when the amniotic fluid obtained during amniocentesis was negative for VZV DNA. If the amniotic fluid is PCR positive for VZV and the ultrasound is normal at 17-21 weeks, the risk of CVS is still low. If the repeat ultrasound is normal at 23-24 weeks the risk of CVS is remote. However, the risk of CVS increases significantly if the ultrasound scan reveals features compatible with CVS and the DNA is found in the amniotic fluid. (Mouly et al., 1997). A negative PCR for VZV in amniotic fluid, and a normal ultrasound scan results from 23 weeks onwards, suggest a low risk of intrauterine infection (Table 3).

\begin{tabular}{cccc}
\hline Weeks of gestation & PCR & $\begin{array}{c}\text { High level } \\
\text { ultrasound }\end{array}$ & $\begin{array}{c}\text { Risk for CVS with } \\
\text { severe malformation }\end{array}$ \\
\hline $\begin{array}{c}\text { Initial } \\
17-21\end{array}$ & $(+)$ Amniocentesis & Normal & Uncertain \\
\hline $\begin{array}{c}\text { Repeat } \\
23-24\end{array} 22-24$ & $\begin{array}{l}(+) \text { Amniocentesis } \\
(+) \text { Amniocentesis } \\
( \pm) \text { cord blood }\end{array}$ & $\begin{array}{c}\text { Normal } \\
\text { Abnormal }\end{array}$ & $\begin{array}{c}\text { Unlikely } \\
\text { High }\end{array}$ \\
$18-22 />23$ & $(-)$ Amniocentesis & Normal & Low \\
\hline
\end{tabular}

Table 3. Prenatal diagnosis using ultrasound and PCR for risk of CVS (Enders \& Miller, 2000)

The prognosis of infants born with CVS is poor, with death in infancy resulting from intractable gastroesophageal reflux, severe recurrent aspiration pneumonia, and respiratory failure due to dysfunction of the autonomic nervous system (Smith \& Arvin, 2009). Nearly $30 \%$ of neonates born with CVS died during the first months of life. A follow-up report in the literature showed that in spite of initially poor prognosis, a good long-term outcome can occur in patients with CVS (Schulze \& Dietzsch, 2000). 


\subsection{Neonatal varicella}

If maternal varicella occurs 1-4 weeks before delivery, up to $50 \%$ of babies may be infected. Approximately $23 \%$ of these develop clinical varicella despite high titers of passively acquired maternal antibodies (Miller et al., 1989). When the mother's rash appeared 7-3 days before delivery, progressively fewer infants had antibodies.

Infection may occur by transplacental viraemia, ascending infection from the birth canal, or through direct contact with infectious lesions during and after delivery. Varicella occurring in the first 12 days of life is described as intrauterine-acquired neonatal varicella infection. If the infection is diagnosed after the 12th day of the neonatal period, VZV is most likely acquired postnatally. (Enders \& Miller, 2000). The severity of intrauterine-acquired neonatal varicella is closely related to the time of onset of the maternal infection, as transplacentally transmitted antibodies may reduce the severity of symptoms in the neonate (Table 1). Generalized neonatal varicella can be fatal if mothers develop varicella rash between 4-5 days before and 2 days after delivery since these neonates are not protected from severe disease by the maternal antibodies. A fatal outcome is more likely if the neonatal disease occurs between 5 and 10 days after delivery. Infants born to mothers with varicella within this high risk period are usually initially well-appearing. Varicella presents with the classical skin lesions, but can disseminate with pneumonia, hepatitis, encephalitis, and severe coagulopathy resulting from liver failure and thrombocytopenia (Prober \& Arvin, 1987). Before VZV immunoglobulin was available, the risk of death among neonates born to mothers with the onset of rash up to four days before delivery was 31\% (Meyers, 1974). The rate decreased to $7 \%$ when the use of VZIG was introduced and neonatal intensive care improved (Miller et al., 1989). Neonatal varicella within the first 4 days after birth has usually been found to be mild (Sauerbrei \& Wutzler, 2001).

When the history of maternal varicella is in the few weeks preceding delivery, the infants may be asymptomatic or may have cutaneous lesions at birth or developing shortly thereafter, but are at low risk of dissemination of varicella disease or complications (Smith \& Arvin, 2008).

Premature neonates younger than 28 weeks gestation must be considered to have an increased risk for severe neonatal varicella during the first 6 weeks after birth (Advisory Committee on Immunization Practices [ACIP], 1996; Deutsche Gesellschaft für Pädiatrische Infektologie [DGPI], 2003). They are unlikely to have protecting maternal antibodies due to the reduced gestation period and the lack the transplacental transfer of maternal IgG to VZV.

The diagnosis of neonatal varicella is usually based on typical clinical picture. The clinical findings may be confirmed by serological methods, detection of VZV DNA in skin swabs or biopsies, or liquor and tissue samples using PCR (Sauerbrei, 2010). When varicella pneumonia is suspected, broncho-alveolar lavage may be obtained for the VZV DNA detection.

We report three clinical cases of neonatal varicella: two transmitted in utero and one acquired postnatally.

\subsubsection{Case report 1}

A 6-day-old baby boy was hospitalized on the first day of his illness with a history of a maculovesicular skin rash noticed on his face and back. On admission, he had normal temperature and he weighed $3960 \mathrm{~g}$. The next day, he was noticed to have haemorrhagic fluid in some of the vesicles, and subsequently he developed pustules with infiltration as 
well as necrosis of the surrounding tissues on the 5th day of the illness. He spiked temperatures up to $38^{\circ} \mathrm{C}$ on day 4 and a few days later (day 6) his condition deteriorated even further. He was spiking fevers up to $39^{\circ} \mathrm{C}$; he had poor appetite and dropped his weight to $3440 \mathrm{~g}$. Peripheral blood analysis performed on the 1st, 5th and 11th day of his illness was within normal limits. His chest was clear on auscultation with no evidence of any obvious respiratory compromise. However, on day 7 a chest $x$-ray demonstrated fine bilateral foci with a minor reaction of interlobular pleura on the right side which was very suggestive of varicella pneumonitis. The patient received $2 \mathrm{ml}$ (50 IU) of intravenous human varicella zoster immunoglobuline (VZIG; Varitect, Germany) on the $2^{\text {nd }}$ day of the admission. He was also given a course of second generation cephalosporin between the day 5 and 9 of his illness. The patient's condition was significantly improved and he was discharged home on the 12th day of his illness.

Of note, the mother had varicella infection 5 days before the delivery. The incubation period for the newborn was 11 days (Figure 2).

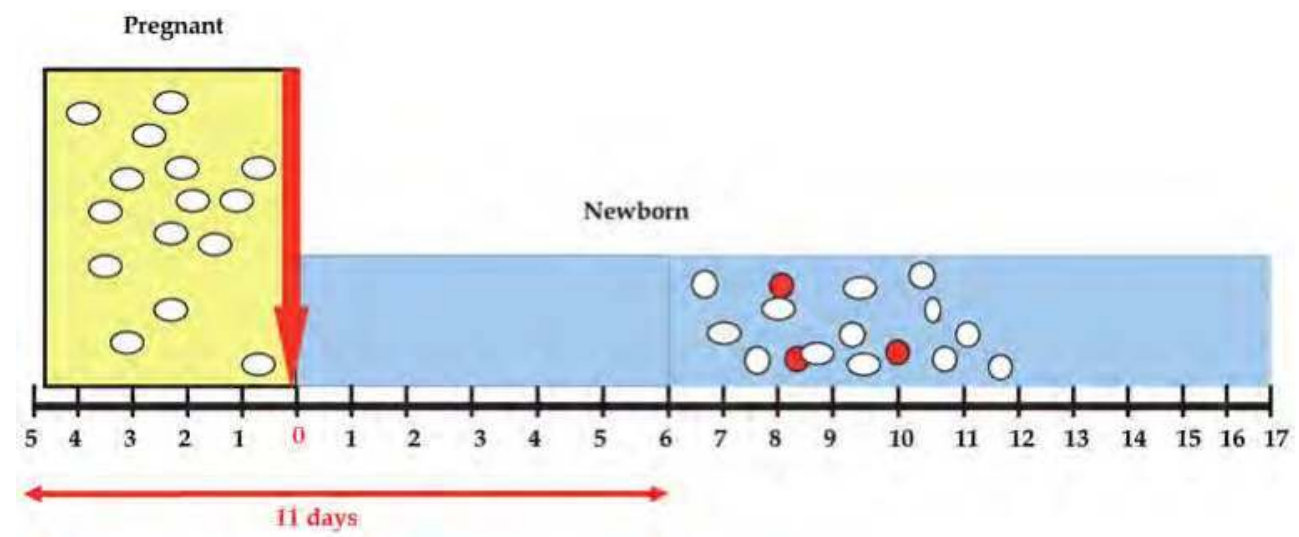

Fig. 2. Newborn varicella aquired from the mother in prenatal period. Varicella of the pregnant woman started at 5 days before delivery; severe varicella of newborn, at 6 days of age. The incubation period of varicella for the newborn was 11days. 


\subsubsection{Case report 2}

A 2-day-old newborn presented with a widespread maculovesicular skin rash and was hospitalized on the first day of his illness (Figure 3).

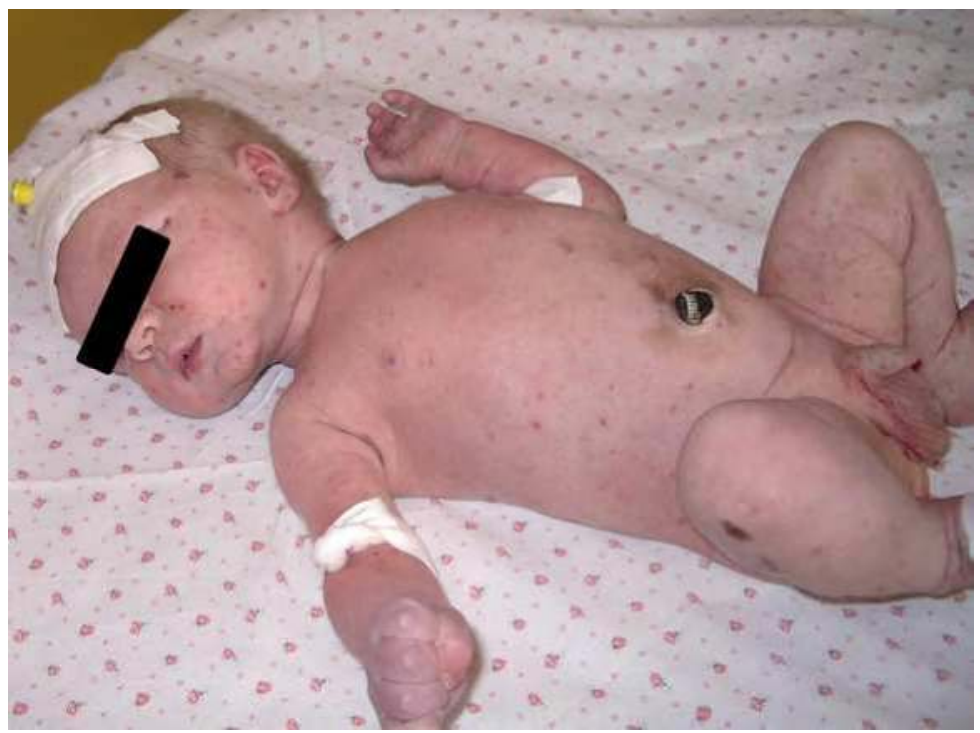

Fig. 3. Male neonate with intrauterine acquired varicella, day 3 of the illness. There was a history of maternal varicella 12 days before the delivery.

On physical examination, the newborn was afebrile and generally appeared well. His peripheral blood analysis was entirely normal. He remained very well during the admission and he was discharged from the hospital on day 4.

The mother had varicella 12 days before the delivery. The incubation period for the newborn was 14 day (Figure 4).

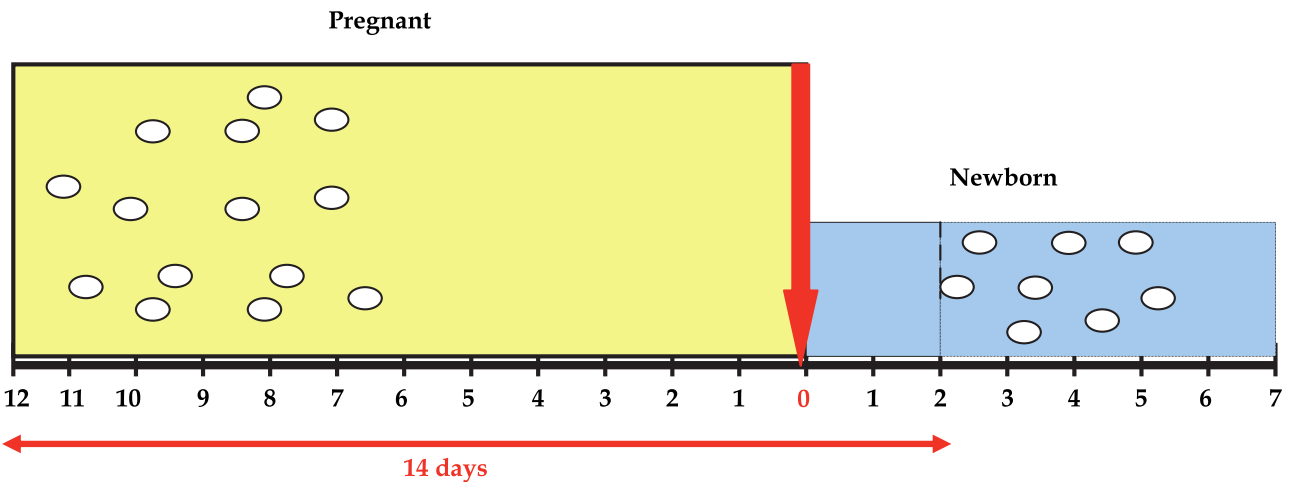

Fig. 4. Prenatally acquired newborn varicella. The mother developed varicella 12 days before the delivery. Mild varicella illness of newborn was diagnosed at 2 days of age. The incubation period of varicella for the neonate was 14 days. 


\subsubsection{Case report 3}

We report a 22-day-old baby boy who at the age of 3 days was in a close contact with his 10year old sister who had clinically unrecognized varicella. Her serological investigation confirmed the diagnosis of varicella by detecting VZV- IgM class antibodies (ELISA, Enzygnost; Dade Behring, Germany). Serum VZV-IgM concentration was raised to 0.939 (pos. > $0.200 \mathrm{OD}$ ) on the $9^{\text {th }}$ day of his illness. Varicella of the neonate started after 14 days of the incubation period. A clinical course of the varicella illness was mild (Figure 5).

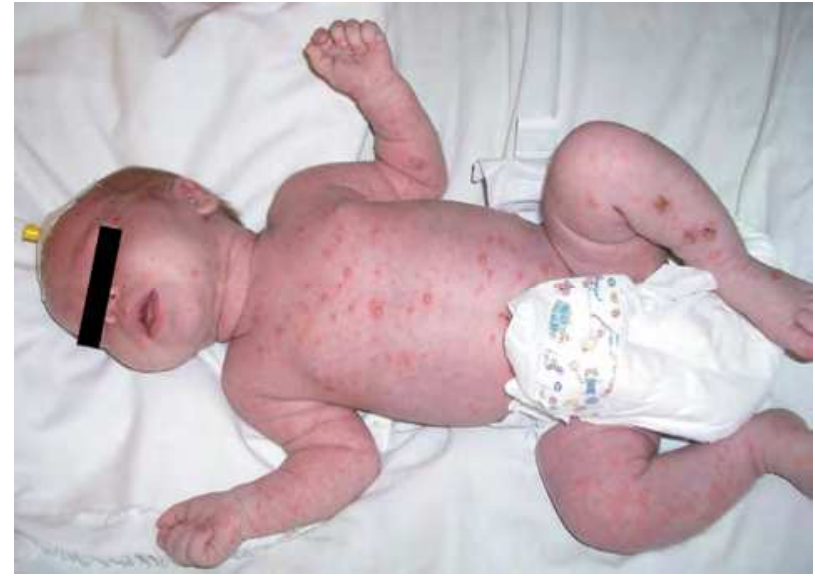

Fig. 5. A 22 day old newborn with postnatally acquired varicella, day 5 of the illness. The index case was a 10 year old sister.

Three days after the delivery, the mother was in direct contact with her daughter who was ill with varicella. As a result, the mother developed varicella thirteen days later, but fortunately the illness was mild (Figure 6).

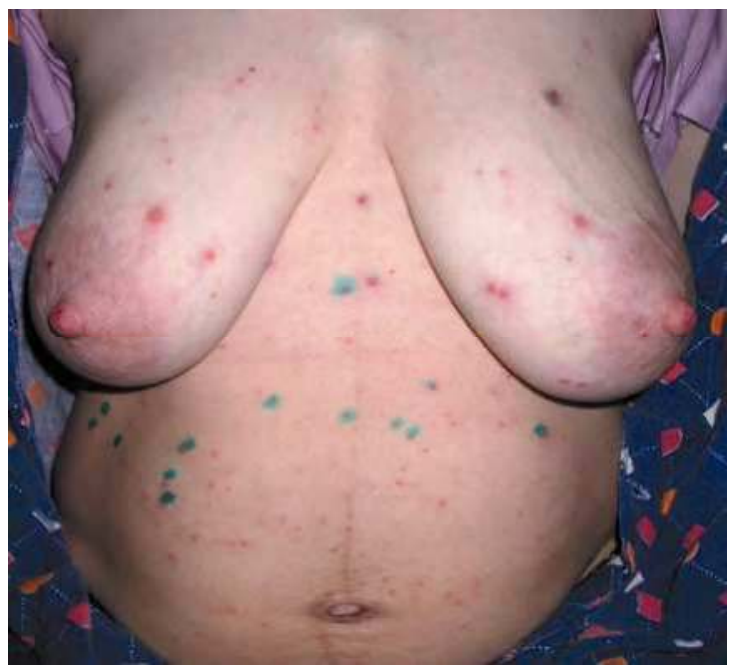

Fig. 6. Maternal varicella, day 4 of the illness. 


\subsection{Herpes zoster in young infants}

Nearly $20 \%$ of infants with intrauterine-acquired VZV primary infection develop herpes zoster in the first or second year of life, usually with uncomplicated course (Sauerbrei \& Wutzler, 2003). The observed risk of zoster when maternal infection occurs before 24 weeks was $0.8 \%$, compared to a $1.7 \%$ observed risk if maternal varicella was after 25 weeks (Enders et al., 1994). The risk of postnatal herpes zoster infection in infancy was $3.8 \%$ in cases when maternal amniotic fluid had been positive for VZV DNA by PCR (Mouly et al., 1997). The symptoms are the same as in adults, although the skin lesions are less prominent and the symptoms of acute neuritis are mild or absent. Unlike adults, children do not suffer with post-herpetic neuralgia (Helgason et al., 2000). Serious complications have been reported in only one case of a four-month-old infant whose mother had had varicella at 17 weeks' gestation. The infant was born full term without complications; however, aged three months, he developed herpes zoster associated with generalized seizures. The clinical picture and VZV DNA detected in his cerebrospinal fluid by PCR were consistent with central nervous system infection (Sauerbrei et al., 2003).

Herpes zoster in infants who acquired VZV in utero has been self-limited. If the zoster is extensive and painful, treatment with acyclovir (initially by intravenous, followed by oral) for seven to 10 days is recommended.

We report two patients with typical herpes zoster, whose mothers had varicella during the second-third trimester of their pregnancy.

\subsubsection{Case report 4}

A thirteen and a half month old girl was hospitalized on the 7th day of her illness because of ongoing restlessness, disturbed sleep, and a rash, which she had developed on day 4 of her restlessness. On examination, she had a right-sided vesicular skin rash along T10-12, L1-2 dermatomes (Picture 2). Otherwise, she appeared generally well. Her peripheral blood analysis was completely normal. The patient received symptomatic treatment and was discharged home 4 days later. VZV-IgG and IgM class antibodies (ELISA, Enzygnost; Dade Behring, Germany) were detected in the blood serum on the 9th and 29th days of the illness. VZV-IgG concentration was 0.135 and 2.142; VZV-IgM was 0.038 and 0.704 , respectively (pos. > 0.200 OD). Of note, she was born prematurely at week 36 of gestation via Caesarean section. Initially she required intubation and ventilation for her backbone injury identified at birth. The mother suffered with moderate varicella during the 26th week of her pregnancy.

\subsubsection{Case report 5}

A 10 month old girl was hospitalized on the 6th day of her illness due to her ongoing restlessness, fever, and a rash noticed on the right side of her chest. On the 5th day she developed a maculovesicular rash and started spiking temperatures up to $38.5^{\circ} \mathrm{C}$. On physical examination, she had vesicular skin lesions observed on the right side of her chest along T6-7 dermatomes. Otherwise, the girl appeared generally well. Peripheral blood analysis was entirely normal. Varicella immune status was established on the 8th and 22nd day of the illness. Her VZV-IgG concentrations were 0.200 and 2.462, and VZV-IgM levels were 0.122 and 0.412 , respectively (pos. $>0.200$ OD). The patient received symptomatic treatment for 6 days and was discharged in good health thereafter. 


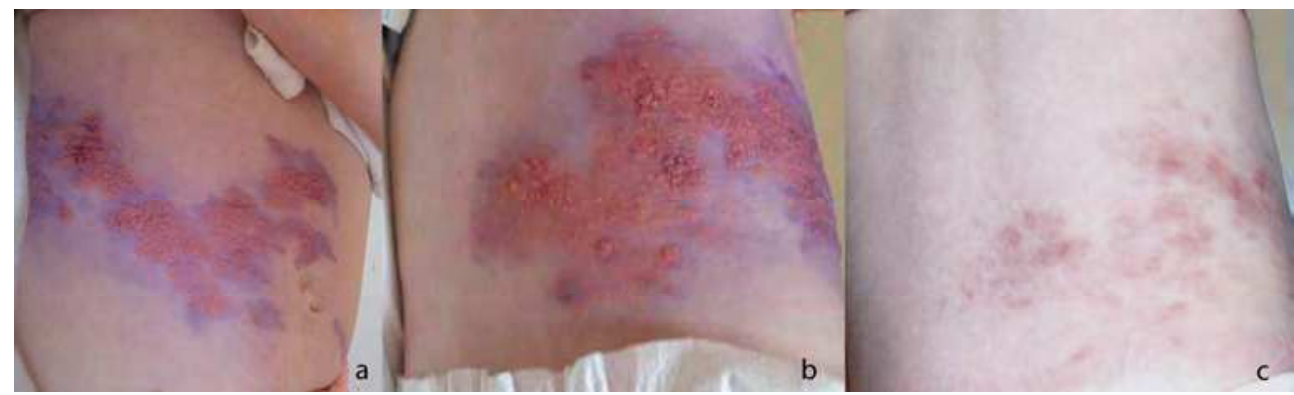

Fig. 7. The patient with herpes zoster following maternal varicella acquired during pregnancy. Day 7 of the illness. a) A typical anterior vesicular skin rash along the T10-12 and L1-2 dermatomes on the right side. b) A typical posterior vesicular skin rash along the T10-12 and L1-2 dermatomes on the right side. c) Post inflammatory skin hyperpigmentation following zoster, day 29 of the illness.

Early manifestation of herpes zoster may be explained by the immature cell-mediated immune response in young children and/or the decrease of maternally derived antibodies (Sauerbrei \& Wutzler, 2000). The hypothesis was confirmed by our two clinical cases. Neither of them had detectable VZV-IgG antibodies at the beginning of the illness. High titers of serum VZV-IgG and IgM antibodies were discovered only 3-4 weeks later.

\section{Management of neonatal varicella}

Varicella zoster immunoglobulin, administered to the infants whose mothers developed varicella (but not herpes zoster) at around term, may attenuate infection and significantly reduce the risk of life-threatening neonatal varicella (Enders, 1985; Miller et al., 1989). VZIG should be given at birth to neonates who meet any of the following criteria (Sauerbrei, 2010):

- $\quad$ their mothers develop rash between 7 days before and 7 days after birth;

- $\quad$ they were born within the last 7 days, the mother is seronegative and they have had significant non-maternal post-natal exposure (e.g. from a sibling);

- they have been exposed to varicella and are at risk because of potentially inadequate transfer of maternal antibodies. This includes neonates born before 28 weeks gestation; or weighing less than 1,000g; or who have had repeated blood sampling with replacement by packed red cell infusion; or those requiring intensive or prolonged special care nursing. VZIG can be issued without antibody testing but, where possible, such infants should be tested.

Other infants whose mothers have a positive history of varicella and/or a positive VZV antibody result will usually have maternal antibody and do not require VZIG. Severe neonatal varicella can occur despite VZIG administration (Reynolds et al., 1999). Neonatal varicella should be treated promptly with acyclovir (Table 4, Figure 8).

Postnatally, the mother and neonate should be isolated from other mothers and babies on the ward, but not from each other. Breast-feeding of neonates exposed to maternal varicella should be encouraged. If the mother has varicella lesions close to the nipple, milk should be expressed until the lesions have crusted (Morgan-Capner et al., 2002). Where other members of the family have varicella at home and the mother is seronegative, discharge should be delayed until the baby is at least 7 days old (Morgan-Capner et al., 2002). 


\begin{tabular}{|l|l|l|}
\hline VZIG after intrauterine exposure to VZV \\
\hline $\begin{array}{l}\text { Neonates whose mothers develop } \\
\text { varicella within 5 days before and } \\
2 \text { days after delivery }\end{array}$ & $\begin{array}{l}\text { Intravenously: 1 ml/kg or } \\
\text { intramuscularly: 125 U or 0.5 } \\
\mathrm{mg} / \mathrm{kg}\end{array}$ & $\begin{array}{l}\text { Immediately after birth or } \\
\text { onset of maternal rash }\end{array}$ \\
\hline VZIG after postnatal exposure & $\begin{array}{l}\text { Intravenously: } 1 \mathrm{ml} / \mathrm{kg} \text { or } \\
\text { intramuscularly: } 125 \mathrm{U} \text { or } 0.5 \\
\mathrm{mg} / \mathrm{kg}\end{array}$ & Within 96 hours after exposure \\
$\begin{array}{l}\text { Premature neonates with negative } \\
\text { maternal varicella history }\end{array}$ & $\begin{array}{l}\text { Intravenously: } 1 \mathrm{ml} / \mathrm{kg} \text { or } \\
\text { intramuscularly: } 125 \mathrm{U} \text { or } 0.5 \\
\mathrm{mg} / \mathrm{kg}\end{array}$ & Within 96 hours after exposure \\
\hline $\begin{array}{l}\text { Premature neonates <28 weeks } \\
\text { gestation or <1,000 g birth weight } \\
\text { history }\end{array}$ & $\begin{array}{l}\text { Acyclovir intravenously: } \\
3 \times 10-15 \text { mg/kg }\end{array}$ & Length of therapy: 5-7 days \\
\hline Antiviral treatment of neonatal varicella
\end{tabular}

Table 4. Administration of VZIG and acyclovir in neonates to prevent neonatal varicella (Sauerbrei, 2010; ACIP, 1996; DGPI, 2003)

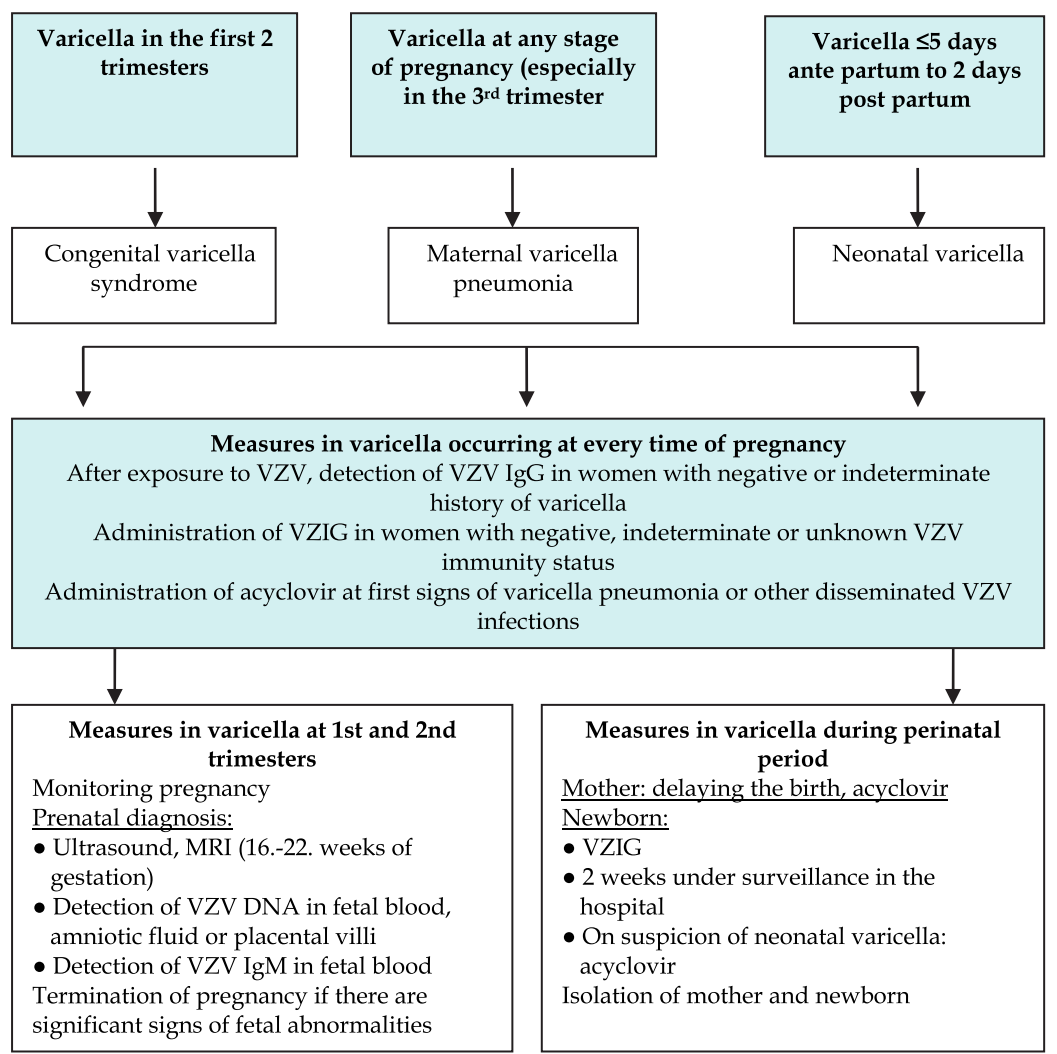

Fig. 8. Measures in case of varicella during pregnancy depending on the point of time of infection (Sauerbrei , 2010) 
All neonates with maternal or other exposure must be followed up for 14-16 days (by the GP, midwife, health visitor or in hospital) and acyclovir should be given if there is any evidence of infection (RCOG, 2001).

\section{Varicella prevention}

The aim of varicella immunisation is to protect from exposure those who are at the most risk of serious illness. Varicella vaccination prepregancy or postpartum is an effective prophylaxis of chickenpox in pregnant women and neonates, and should be considered for seronegative women before pregnancy or in the postpartum period. Live-attenuated varicella vaccine, made from the OKA strain, was licensed in the United States in 1995 and is currently recommended for universal administration in early childhood. Following its introduction, the incidence of primary varicella infection has fallen by $90 \%$ and the mortality related to the condition has decreased by two-thirds (Ngyuen et al., 2005). The vaccine has also been shown to be safe and effective in preventing chickenpox in adults (Gershon et al., 1990). The two-dose varicella vaccine schedule administered to suseptible adolescents and adults provides about $75 \%$ protection, and the single-dose schedule in children about $95 \%$ protection against clinical varicella (Annunziato \& Gershon, 2000). In both age groups, most of the breakthrough infections are modified, and vaccinated individuals who contract varicella develop fewer lesions and less systemic illness than unvaccinated individuals (Immunisation against infections disease, Varicella, online, updated 2011). Currently, a twodose regimen of varicella vaccine, given four to eight weeks apart, is recommended to susceptible individuals (Gardella \& Brown, 2007; Department of Health, 2004). In the UK, varicella immunisation is only offered to specific individuals who are in regular or close contact with those at risk (Department of Health, 2004).

Women who are pregnant should not receive varicella vaccine and pregnancy should be avoided for three months following the last dose (Department of Health, 2004). Studies have shown that the vaccine virus is not transferred to the infant through breast milk (Bohlke et al., 2003) and therefore breast feeding women can be vaccinated if necessary.

Inadvert exposures to the vaccine in pregnancy have been reported to a register. No cases of congenital varicella have been reported so far. Furthermore, the rate of occurrence of congenital anomalies was similar to that reported in the general population (Merck Pregnancy Registry Program, 2003).

The varicella immune status of women planning a pregnancy can be determined by obtaining a past history of primary varicella infection or by checking the serum for varicella antibodies in those who have no history or uncertain history of previous infection. A previous history of varicella infection is $97-99 \%$ predictive of the presence of serum varicella antibodies (CDC, 1996). Routine serologic testing is not recommended for pregnant women who received 2 doses of varicella vaccine, since seroconvertion rate after the second dose of varicella immunization is as high as $99 \%$ (Kuter et al., 1995). Non-immune pregnant women should be advised to avoid exposure to chickenpox or shingles and to immediately inform healthcare workers of a potential exposure. The US Advisory Committee on Immunization Practices recommends that postpartum women without evidence of immunity be given the first dose of vaccine before discharge from the hospital, and the second dose of vaccine at the follow-up postpartum visit six to eight weeks after delivery (Marin et al., 2007).

If the pregnant woman has had a significant exposure to varicella infection or shingles, a careful history must be taken to confirm the significance of the contact, any past history of 
chickenpox or shingles, vaccination, and the susceptibility of the patient. Significant contact is defined as contact in the same room for 15 minutes or more, face-to-face contact and contact in the setting of a large open ward. The UK Advisory Group on Chickenpox considers any close contact during the period of infectiousness to be significant (Nathwani et al., 1998). If the woman's immunity to chickenpox is unknown and if there is any doubt about previous infection, or if there is no previous history of chickenpox or shingles, serum should be tested for VZV IgG. At least $80-90 \%$ of women tested will have VZ IgG and can be reassured (McGregor et al., 1987).

If the woman has a past history of chickenpox or shingles or two doses of a varicella containing vaccine, and is not immunosuppressed, protection can be assumed and reassurance given.

If the pregnant woman is VZV negative, has indeterminate or unknown serologic status, she should be given VZIG as soon as possible (Figure 1), preferably within 72-96 $\mathrm{h}$ after the exposure (Smith \& Arvin, 2009). VZIG is effective when given up to 10 days after contact (RCOG, 2001). VZIG recommended intramuscularly at a concentration of $125 \mathrm{U} / 10 \mathrm{~kg}$ of body weight, up to a maximum of $625 \mathrm{U}$ (ACIP, 1996) or $0.5 \mathrm{ml} / \mathrm{kg}$ of body weight (DGPI, 2003). A dosage of $1 \mathrm{ml} / \mathrm{kg}$ of body weight can be administered intravenously as alternative (DGPI, 2003). The primary reason for VZIG prophylaxis in pregnant women is to reduce severity of maternal disease and reduce the risk of fetal infection for women contracting varicella in the first 20 weeks of pregnancy. The risk of fatal varicella is estimated to be about five times higher in pregnant than non-pregnant adults, with fatal cases concentrated late in the second or early in the third trimester (Enders \& Miller, 2000). One study showed a significant reduction in the risk of congenital VZV infection in women who developed varicella after VZIG prophylaxis compared with women who developed varicella without VZIG prophylaxis; however, the study was too small to assess whether the risk of CVS was reduced (Enders et al., 1994). A case of CVS has been reported in the infant of a woman exposed at the eleventh week of gestation and who developed clinical varicella despite postexposure prophylaxis with VZIG (Pastuszak et al., 1994). About $50 \%$ of susceptible pregnant women given VZIG after a household exposure to chickenpox will develop clinical varicella, although the disease may be attenuated; the clinical attack rates are similar whether VZIG is given within 72 hours or four to ten days after contact (Enders \& Miller, 2000; Miller et al., 1993). A further quarter will be infected sub-clinically (Miller et al., 1993). Severe maternal varicella may still occur despite VZIG prophylaxis. Prompt treatment with acyclovir is indicated in such cases. Women who have had exposure to chickenpox or shingles (regardless of whether or not they have received VZIG) should be asked to notify their doctor or midwife early if a rash develops (Nathwani et al., 1998).

Neither immunoglobulin nor acyclovir treatment have been shown to prevent vertical transmission or CVS (McKendrick et al., 2007).

If there is another exposure to chickenpox or shingles three weeks or more after the first use of VZIG, the need for VZIG needs to be reassessed. If more than six weeks have elapsed since first issue, antibody testing should be performed using a new (recent) sample ((Health Protection Agency [HPA], 2011).

As VZIG does not always prevent chickenpox, the woman should be managed as being possibly infectious 8-28 days after VZIG, and should be asked to contact her family doctor if she develops a rash. Up to $50 \%$ may develop a modified form of disease. Maternal pneumonia associated with chickenpox infection has been reported despite the timely VZIG administration (HPA, 2001). 


\section{References}

Advisory Committee on Immunization Practices (ACIP). (1996). Prevention of varicella. Morbidity and Mortality Weekly Report, Vol.45, pp. 1-36

Annunziato, P.W. \& Gershon, A.A. (2000). Primary vaccination against varicella, In: Varicella-zoster virus, A.M. Arvin \& A.A. Gershon (Eds), pp. ??? Cambridge, Cambridge University Press

Bohlke, K.; Galil, K.; Jackson, L.A.; Schmid, D.S.; Starkovich, P.; Loparev, V.N. \& Seward, J.F. (2003). Postpartum varicella vaccination: is the vaccine virus excreted in breast milk? Obstetrics $\mathcal{E}$ Gynecology. Vol.102 (5 Pt 1), pp. 970-977

Brown, N.W.; Parsons, A.P. \& Kam, P.C. (2003). Anaesthetic considerations in a parturient with varicella presenting for Caesarean section. Anaesthesia, Vol.58, No.11, pp. 10921095

Centers for Disease Control and Prevention (CDC). (1996). Prevention of varicella: Recommendations of the Advisory Committee on Immunization (ACIP). Morbidity and Mortality Weekly Report, Vol.45 (RR-11), pp. 1-25

Chandra, P.C.; Patel, H., Schiavello, H.J. \& Briggs, S.L. (1998). Successful pregnancy outcomeafter complicated varicella pneumonia. Obstetrics \& Gynecology, Vol.92, (4 Pt 2), pp. 680-682

Chickenpox, pregnancy and the newborn. (2005). Drug and Therapeutics Bulletin, Vol.43, No.9, pp. 69-72 [Downloaded from dtb.bmj.com on May 16, 2011 - Published by group.bmj.com]

Daley, A.J.; Thorpe, S. \& Garland, S.M. (2008). Varicella and the pregnant woman:prevention and management. Australian and New Zealand J of Obstetrics and Gynaecology, Vol.48, No.1 (Feb), pp. 26-33 Department of Health. (2004). Varicella [online]. Available:

http://www.dh.gov.uk/assetRoot/04/07/31/40/04073140.pdf [Accessed 18 August 2005]

Deutsche Gesellschaft für Pädiatrische Infektiologie. (2003). Handbuch 2003: Infektionen im Kindesalter, pp. 732-739, Futuramed, München

Enders, G. \& Miller, E. (2000). Varicella and herpes zoster in pregnancy and the newborn. In: Varicella-zoster virus. Virology and Clinical Management, A.M. Arvin \& A.A. Gershon (Eds.), pp. 317-347, University Press, Cambridge

Enders, G.; Miller, E.; Cradock-Watson, J.; Bolley, I. \& Ridehalgh, M. (1994). Consequences of varicella and herpes zoster in pregnancy: prospective study of 1739 cases. Lancet, Vol.343, No.8912 (Jun 18), pp. 1548-1551

Enders, G. (1985). Management of varicella-zoster contact and infection in pregnancy using a standartized varicella-zoster ELISA test. Postgraduate Medical Journal, Vol.61, (Suppl 4), pp. 23-30

Gardella, C. \& Brown, Z.A. Managing varicella zoster infection in pregnancy. (2007). Cleveland Clinic Journal of Medicine, Vol.74, No.4 (Apr), pp. 290-296

Gershon, A.A. \& Steinberg, S.P. (1990). Live attenuated varicella vaccine: protection in healthy adults compared with leukemic children. National Institute of Allergy and Infectious Diseases Varicella Vaccine Collaborative Study Group. Journal of Infectious Diseases, Vol.161, No.4, pp. 661-666

Gershon, A.A. (2001). Chickenpox, measles, and mumps. In: Infections of the Fetus and Newborn Infant, 5th ed., J. Remington, J. Klein, (Eds.), pp. 683-732, Saunders, Philadelphia 
Haake, D.A.; Zakowski, P.C.; Haake, D.L. \& Bryson, X.J. (1990). Early treatment with acyclovir for varicella pneumonia in otherwise healthy adults: retrospective controlled study and review. Reviews of Infectious Diseases, Vol.12, No.5 (Sep-Oct), pp. $788-798$

Harger, J.H.; Ernest, J.M.; Thurnau, G.R.; Moawad, A.; Momirova, V.; Landon, M.B.; Paul, R.; Miodovnik, M.; Dombrowski, M.; Sibai, B. \& Van Dorsten P. (2002). Risk factors and outcome of varicella-zoster virus pneumonia in pregnant women. Journal of Infectious Diseases, Vol. 185, No.4, (Jan 17), pp. 422-427 Health Protection Agency, UK (2011). Guidance on viral rash in pregnancy [online]. Available: http://www.hpa.org.uk/web/HPAweb\&HPAwebStandard/HPAweb_C/1195733 745858

Helgason, S; Petursson, G.; Gudmundsson, S. \& Sigurdsson, J.A. (2000). Prevalence of postherpetic neuralgija after a first episode of herpes zoster: prospective study with long term follow up. British Medical Journal, Vol.321, No.7264 (Sep 30), pp. 794-796

Petursson, G. \& Sigurdsson, J.A. (2000). Prevalence of postherpetic neuralgia after a first episode of herpes zoster: prospective study with long term follow up. British Medical Journal, Vol.321, No.7264, pp. 794-796

Heuchan, A.M. \& Isaacs, D. (2001). The management of varicella-zoster virus exposure and infection in pregnancy and the newborn period. The Medical Journal of Australia, Vol.174, No.6, pp. 288-292

Hinshaw, K. \& Fayyad, A. (2000). The management of early pregnancy loss - (25) Oct 2000 [online]. Available: http://www.rcog.org.uk/printindex.asp?PageID=515 [Accessed 18 August 2005]

Department of Health. (2006). Varicella, In: Immunisation against infectious disease - The Green Book, D. Salisbury, M. Ramsy, K. Noakes, (Eds), pp.421-442, TSO, UK (updated 2011). [online]. Available:

http://www.dh.gov.uk/prod_consum_dh/groups/dh_digitalassets/@dh/@en/d ocuments/digitalasset/dh_128074.pdf.

Kempf, W.; Meylan, P.; Gerber, S.; Aebi, C.; Agosti, R.; Büchner, S.; Coradi, B.; Garweg, J.;Hirsch, H.H.; Kind, C.; Lauper, U.; Lautenschlager, S.; Russer, P.; Ruef, C.;Wunderli, W. \& Nadal, D. (2007). Swiss recommendations for the management of

varicella zoster virus infections. Swiss Medical Weekly, Vol.137, No.17-18 (May 5), pp. 239-251

Knowles, S.J.; Grindy, K.; Cahill, I. \& Cafferkey M.T. (2004). Susceptibility to infection rash illness in pregnant women from diverse geographical regions. Communicable Disease and Public Health, Vol.7, No.4, pp. 344-348

Kuter, B.J.; Ngai, A.; Patterson, C.M.; Staehle, B.O.; Cho, I.; Matthews, H.; Provost, P.J. \& White, C.J. (1995). Safety, tolerability, and immunogenicity of two regimens of Oka/Merck varicella vaccine (Varivax) in healthy adolescents and adults. Vaccine, Vol.13, No.11, pp. 967-972

Laforet, E.G. \& Lynch, C.L. Jr. (1947). Multiple congenital defects following maternal varicella. New England Journal of Medicine, Vol.236, No.15 (April 10), pp. 534-537

McGregor, J.A.; Mark, S.; Crawford, G.P. \& Levin, M.J. (1987). Varicella zoster antibody testing in the care of pregnant women exposed to varicella. American Journal of Obstetrics and Gynecology, Vol.157, No.2, pp.281-284

Marin, M.; Guris, D.; Chaves, S.S.; Schmid, S. \& Seward, J.F. (2007). Prevention of varicella: recommendations of the Advisory Committee on Immunization Practices (ACIP). 
Morbidity and Mortality Weekly Report. Recommendations and Reports, Vol.56 (RR-4), pp. $1-40$

McKendrick, M.W.; Lau, J.; Alston, S. \& Bremner, J. (2007). VZV infection in pregnancy: a retrospective review over 5 years in Sheffield and discussion on the potential utilization of varicella vaccine in prevention. Journal of Infection, Vol.55, No.1, pp.6467

Merck Pregnancy Registry Program (2003). Merck/CDC pregnancy registry for Varivax, the eight annual report

Meyers, J.D. (1974). Congenital varicella in term infants: risk reconsidered. Journal of Infectious Diseases, Vol.129, No.2 (Feb), pp. 215-217

Miller, E.; Cradock-Watson, J.E. \& Ridehalgh, M.K. (1989). Outcome in newborn babies given anti-varicella zoster immunoglobulin after perinatal maternal infection with varicella zoster virus. Lancet, Vol.2, No.8659 (Aug 12), pp. 371-373

Miller, E.; Marshall, R. \& Vurdien, J.E. (1993). Epidemiology, outcome and control of varicella-zoster infection. Reviews of Medical Microbiology, Vol.4, pp. 222-230

Morgan-Capner, P. \& Crowcroft, N.S. (2002). Guidelines on the management of, and exposure to, rash illness in pregnancy (including consideration of relevant antibody screening programmes in pregnancy). Communicable Disease and Public Health, Vol.5, No.1 (Mar), pp. 59-71

Mouly, F.; Mirlesse, V.; Meritel, J.F.; Rozenberg, F.; Poissonier, M.H.; Lebon, P. \& Daffos, F. (1997). Prenatal diagnosis of fetal varicella-zoster virus infection with polymerase chain reaction of amniotic fluids in 107 cases. American Journal of Obstetrics and Gynecology, Vol. 177, No.4 (Oct), pp. 894-898

Nathwani, D.; Maclean, A.; Conway, S. \& Carrington, D. (1998). Varicella infections in pregnancy and the newborn. Journal of Infection, Vol.36, (Suppl 1), pp. 59-71

Nguyen, H.Q.; Jumaan, A.O. \& Seward, J.F. (2005). Decline in mortality due to varicella after implementation of varicella vaccination in the United States. New England Journal of Medicine, Vol.352, No.5 (Feb 3), pp. 450-458

Office for National Statistics (2005). Deaths 2001: Childhood, infant and perinatal mortality: stillbirths, infant deaths and childhood deaths under 15 (rates) [online]. Available: http:/ / www.statistics.gov.uk/STATBASE/xsdataset.asp?\%20\%20\%20More=Y\&vl $\mathrm{nk}=6667 \& \mathrm{All}=\mathrm{Y} \& \mathrm{~B} 2 . \mathrm{x}=24 \& \mathrm{~B} 2 . \mathrm{y}=11$ [Accessed 18 August 2005]

Oral antihistamines for allergic disorders. (2002). Drug and Therapeutics Bulletin, Vol.40, pp. 59-62

Pastuszak, A.L.; Levy, M.; Schick, B.; Zuber, C.; Feldkamp, M.; Gladstone, J.; Bar-Levy, F.; Jackson, E, Donnenfeld, A.; Meschino, W. \& Koren, G. (1994). Outcome after maternal varicella infection in the first 20 weeks of pregnancy. New England Journal of Medicine, Vol.330, No.13 (Mar 31), pp. 901-905

Prober, C.G. \& Arvin, A.M. (1987). Perinatal viral infections. European Journal of Clinical Microbiology, Vol.6, No.3 (Jun), pp. 245-261

Prober, C.G.; Gershon, A.A.; Grose, C.; McCracken, G.H. Jr.\& Nelson, J.D. (1990). Consensus: varicella-zoster infections in pregnancy and the perinatal period. Pediatric Infectious Disease Journal, Vol.9, No.12 (Dec), pp. 865-869 Prodigy. (2004). Chickenpox [online]. Available from: www.prodigy.nhs.uk/guidance.asp?gt= Chickenpox [Accessed 18 August 2005]

Ratanjamit, C.; Vinther Skriver, M.; Jepsen, P.; Chongsuvivatwong, V.; Ober, J. \& Sorensen, H.T. (2003). Adverse pregnancy outcome in women exposed to acyclovir during 
pregnancy: a population based observational study. Scandinavian Journal of Infectious Diseases, Vol.35, No.4, pp. 255-259

Rawson, H.; Crampin, A. \& Noah, N. (2001). Deaths from chickenpox in England and Wales.1995-7: analysis of routine mortality data. Britsh Medical Journal, Vol.323, pp. 1091-1093

Reynolds, L.; Struik, S. \& Nadel, S. Neonatal varicella: varicella zoster immunoglobulin (VZIG) does not prevent disease. (1999). Archives of Disease in Childhood. Fetal and Neonatal Ed, Vol.81, No.1 (Jul), F69-70

Riley, L. (1998). Varicella-zoster virus infection in pregnancy. Available from: UptoDate, 34 Washington St., Suite 100, Wellesley, MA 02481, on CD-ROM and by subscription at www.uptodate.com

Royal College of Obstetricians and Gynaecologists. (2001). Chickenpox in pregnancy [online]. Available:

http://www.rcog.org.uk/resourses/Public/pdf/Chickenpox_No13.pdf

[Accessed 18 August 2005]

Sauerbrei, A. \& Wutzler, P. (2000). The congenital varicella sindrome. Journal of Perinatology, Vol.20 (8 Pt 1), pp. 548-554

Sauerbrei, A. \& Wutzler, P. (2003). Das fetale Varizellensyndrom. Monatsschrift fur Kinderheilkunde, Vol.151, pp. 209-213

Sauerbrei, A,; Pawlak, J.; Luger, C. \& Wutzler, P. (2003). Intracerebral varicella-zoster virus reactivation in congenital varicella sindrome. Development Medicine and Child Neurology, Vol.45, No.12 (Dec), pp. 837-840

Sauerbrei, A. \& Wutzler, P. (2005). Varicella-zoster virus infections during pregnancy: Epidemiology, clinical symptoms, diagnosis, preventon and therapy. Current Pediatric Reviews, Vol.1, pp. 205-216

Sauerbrei, A. \& Wutzler, P. (2001). Neonatal varicella. Journal of Perinatology, Vol.21, No.8 (Dec), pp. 545-549

Sauerbrei, A. (2010). Review of varicella-zoster virus infections in pregnant women and neonates. Health, Vol.2, No.2, pp. 143-152

Schulze, A. \& Dietzsch, H.J. (2000). The natural history of varicella embryopathy: A 25-year follow-up. Journal of Pediatrics, Vol.137, No.6 (Dec), pp. 871-874

Sissons, J.G. (2003). Herpesviruses (ecluding Epstein-Barr virus). In: Oxford Textbook of Medicine, D.A. Warrell et al. (Eds.), Fourth Editon, Vol.1, Sections 1-10, Oxford University press, Oxford

Smith, C.K. \& Arvin, M.A. (2009). Varicella in the fetus and newborn. Seminars in Fetal \& Neonatal Medicine, Vol.14, No.4 (Aug), pp. 209-217

Stone, K.M.; Reiff-Eldridge, R.; White, A.D.; Cordero, J.F.; Brown, Z.; Alexander, E.R. \& Andrews, E.B. (2004). Pregnancy outcomes following systemic prenatal acyclovir exposure: conclusions from the International acyclovir pregnancy registry, 19841999. Birth Defects Research.Part A, Clinical and Molecular Teratology, Vol.70, No.4 (Apr), pp. 201-207.

Tan, M.P. \& Koren, G. (2006). Chickenpox in pregnancy: revisited. Reproductive Toxicology, Vol.21, No.4 (May), pp. 410-420

Wallace, M.R.; Bowler, W.A.; Murray, N.B.; Brodine, S.K. \& Oldfield, E.C. (1992). Treatment of adult varicella with oral acyclovir. A randomized, placebo-controlled trial. Annals of Internal Medicine, Vol.117, No.5 (Sep 1), pp. 358-363 


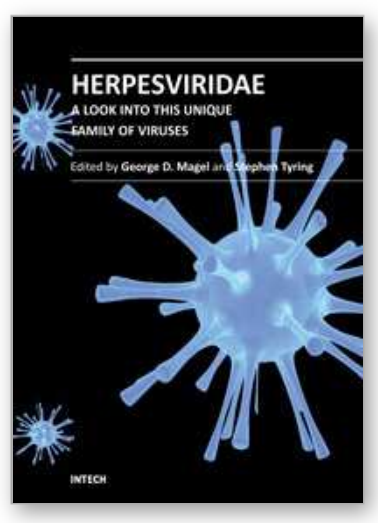

\author{
Herpesviridae - A Look Into This Unique Family of Viruses \\ Edited by Dr. George Dimitri Magel
}

ISBN 978-953-51-0186-4

Hard cover, 320 pages

Publisher InTech

Published online 07, March, 2012

Published in print edition March, 2012

In order to fully understand the nature of viruses, it is important to look at them from both, their basic science and clinical, standpoints. Our goal with this book was to dissect Herpesviridae into its biological properties and clinical significance in order to provide a logical, as well as practical, approach to understanding and treating the various conditions caused by this unique family of viruses. In addition to their up-to-date and extensive text, each chapter is laced with a variety of diagrams, tables, charts, and images, aimed at helping us achieve our goal. We hope that this book will serve as a reference tool for clinicians of various specialties worldwide.

\title{
How to reference
}

In order to correctly reference this scholarly work, feel free to copy and paste the following:

Irena Narkeviciute and Jolanta Bernatoniene (2012). Varicella Zoster Virus Infection in Pregnancy, Herpesviridae - A Look Into This Unique Family of Viruses, Dr. George Dimitri Magel (Ed.), ISBN: 978-953-510186-4, InTech, Available from: http://www.intechopen.com/books/herpesviridae-a-look-into-this-unique-familyof-viruses/varicella-zoster-virus-infection-in-pregnancy

\section{INTECH}

open science | open minds

\section{InTech Europe}

University Campus STeP Ri

Slavka Krautzeka 83/A

51000 Rijeka, Croatia

Phone: +385 (51) 770447

Fax: +385 (51) 686166

www.intechopen.com

\section{InTech China}

Unit 405, Office Block, Hotel Equatorial Shanghai

No.65, Yan An Road (West), Shanghai, 200040, China

中国上海市延安西路65号上海国际贵都大饭店办公楼 405 单元

Phone: +86-21-62489820

Fax: $+86-21-62489821$ 
(C) 2012 The Author(s). Licensee IntechOpen. This is an open access article distributed under the terms of the Creative Commons Attribution 3.0 License, which permits unrestricted use, distribution, and reproduction in any medium, provided the original work is properly cited. 